\title{
BRIEF

\section{Milestones as a Faculty Development Tool for Career Academic Physicians}

Rebecca K. Kemmet, MD; Gregory H. Blake, MD, MPH; Robert E. Heidel, PhD; G. Anthony Wilson, MD

\begin{abstract}
BACKGROUND AND OBJECTIVES: The Accreditation Council for Graduate Medical Education (ACGME) has implemented milestones for progression of residents. Career academic physicians would benefit from similar concrete guidance for scholarly activity and faculty development. After developing milestones across six recognized competencies among our family medicine academicians, we acknowledged the potential benefit of expanding the development of milestones throughout the academic medical center.
\end{abstract}

METHODS: Milestones that we previously developed were modified by departmental leaders within our institution reflecting levels of career development based on benchmarks in each field. These objective measures for guiding maturation of clinical and academic skill sets were then circulated to clinicians in five residency programs throughout our academic medical center for self-evaluation. We analyzed the completed surveys to determine if an association exists between years in academics and rank across each area of competency.

RESULTS: We received fifty-three responses from the 91 faculty invited. We noted a significant association in the competency of medical knowledge with progression from assistant to full professor, and we noted a trend toward significance in professionalism and progression from assistant to full professor. These objective measures of clinician development and competency suggest association with levels of academic career development by rank within the institution.

CONCLUSIONS: This rubric can be helpful for directing faculty development and faculty mentorship. These milestones are general enough that other physician specialties may be able to adopt them for their own needs.

(Fam Med. 2022;54(3):207-212.)

doi: 10.22454/FamMed.2022.700483

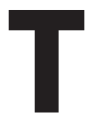
he importance of evaluating competencies in physician education has been prioritized over the last decade by academic governing bodies. The Accreditation Council for Graduate Medical Education (ACGME) has worked to establish milestones ${ }^{1}$ to ensure uniform educational standards in graduate medical education. The need for a standardized approach velopment.

\section{Methods}

We chose to model the educational milestones created by the ACGME to develop milestones for faculty that we previously developed and utilized in our own family medicine department. ${ }^{6}$ To externalize our milestones for use in additional medical specialties, we requested input from educators and specialists throughout our medical center. The example rubric (Figure 1) shows the changes made for the radiology department as an example of how the milestones were customized for each discipline. We then administered the milestones as a self-reported survey to physician educators in five residency programs (Ob/Gyn, oral/maxillofacial surgery (OMFS), radiology, pathology, surgery) at the University of Tennessee Graduate School of Medicine.

\section{Statistical Methods}

We performed frequency and descriptive statistics to describe the demographic characteristics of the sample. We assessed the distributions of each professional rating for the statistical assumptions of normality and homogeneity of variance. Since we considered the response sets for the ratings ordinal in terms of measurement, if both statistical assumptions were met, we considered the ratings to be at an interval level of measurement and we utilized parametric one-way an objective set of criteria for levels of development in each area of competency to help guide academicians in scholarly activity and faculty de-
From Department of Family Medicine (Drs Kemmet, Blake, and Wilson), and Department of Surgery (Dr Heidel) University of Tennessee Graduate School of Medicine, Knoxville, TN. 
analyses of variance to compare the academic appointment groups. If a significant main effect was detected, then we employed post hoc tests using Tukey's test for pairwise comparisons. Means (M) and standard deviations (SD) were reported for the parametric analyses. If either or both statistical assumptions were violated, then we performed nonparametric Kruskal-Wallis tests to test for significant main effects. We used Mann-Whitney U tests to test for post hoc effects. We reported medians and interquartile ranges (IQR) for the nonparametric analyses. We performed all analyses using SPSS Version 26 (Armonk, NY: IBM Corp.) and statistical significance was assumed at an $\alpha$ value of 0.05 .

The Institutional Review Board at the University of Tennessee Graduate School of Medicine examined and approved this study.

\section{Results}

The demographic characteristics of the sample are presented in Table 1 . The average number of years in academics was 15.8. The majority of faculty members were in the Ob-Gyn department, and most participants were assistant professors.

In total, 53 academic physicians responded. The milestones were administered for self-report and the results are analyzed in Table 2 . The most significant findings showed correlation between academic rank (assistant vs full professor) and levels of progression in the competencies of medical knowledge and professionalism. Competencies of patient care, systems-based practice, and practicebased learning also showed statistical correlation with progression from assistant to full professor. The levels of associate professor did not show significant correlation to levels of academic achievement when compared to academic rank above or below.

Figure 1: Milestones for Academic Physicians, Edited for Department of Radiology

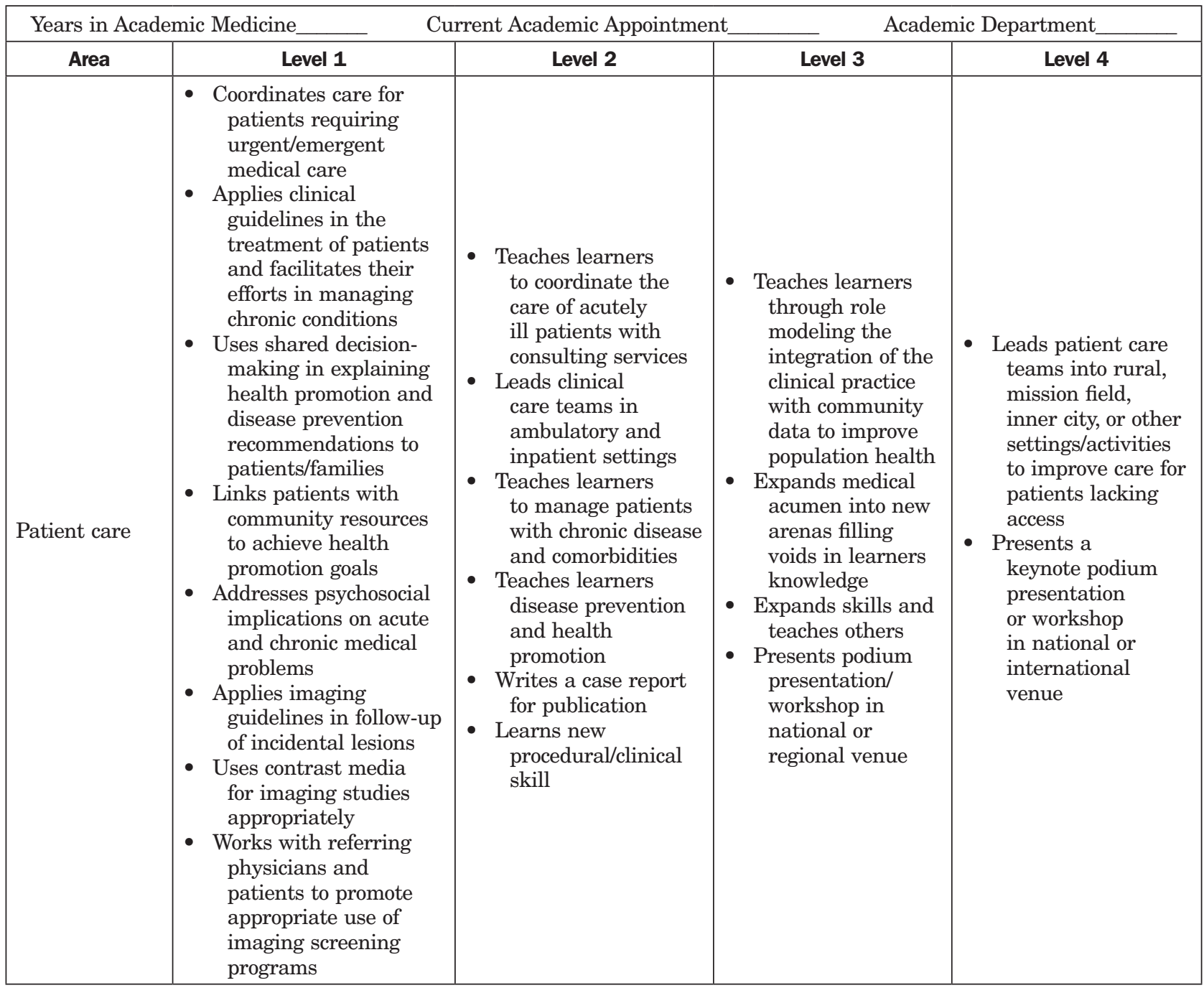


Figure 1: Continued

\begin{tabular}{|c|c|c|c|c|}
\hline & Level 1 & Level 2 & Level 3 & Level 4 \\
\hline $\begin{array}{l}\text { Medical } \\
\text { knowledge }\end{array}$ & $\begin{array}{l}\text { - Achieves board } \\
\text { certification } \\
\text { - Teaches learners } \\
\text { to coordinate the } \\
\text { care of acutely ill } \\
\text { patients requiring } \\
\text { interventional } \\
\text { radiology services } \\
\text { - Teaches learners to } \\
\text { manage patients with } \\
\text { contrast reactions and } \\
\text { allergies }\end{array}$ & $\begin{array}{l}\text { - Maintains } \\
\text { certification } \\
\text { - Writes a review } \\
\text { article for } \\
\text { publication or a } \\
\text { book chapter } \\
\text { - Demonstrates } \\
\text { ability to effectively } \\
\text { convey medical } \\
\text { knowledge to } \\
\text { learners } \\
\text { - Presents a poster at } \\
\text { a conference } \\
\text { - Presents/leads a } \\
\text { topic/workshop at a } \\
\text { conference }\end{array}$ & $\begin{array}{l}\text { - Develops local } \\
\text { clinical practice } \\
\text { or imaging } \\
\text { guidelines } \\
\text { - Serves as a } \\
\text { reviewer for } \\
\text { medical journals }\end{array}$ & $\begin{array}{l}\text { - } \quad \text { Authors a medical } \\
\text { book } \\
\text { - } \quad \text { Serves as editor of } \\
\text { textbook } \\
\text { - } \quad \text { Participates in } \\
\text { national guideline } \\
\text { setting panels } \\
\text { - } \text { Is invited to } \\
\text { comment in } \\
\text { national press on } \\
\text { areas of expertise } \\
\text { - Chairs a } \\
\text { national medical } \\
\text { organization } \\
\text { - Serves on national } \\
\text { educational } \\
\text { committee } \\
\text { - Directs national } \\
\text { meetings or } \\
\text { conferences } \\
\end{array}$ \\
\hline $\begin{array}{l}\text { System-based } \\
\text { practice }\end{array}$ & $\begin{array}{l}\text { - Analyzes personal } \\
\text { and systemic causes } \\
\text { of medical errors } \\
\text { common to medical } \\
\text { specialty } \\
\text { - } \quad \text { Partners with patients } \\
\text { to increase efficiency } \\
\text { and effectiveness in } \\
\text { patient care being } \\
\text { conscious of resource } \\
\text { use and cost in your } \\
\text { practice } \\
\text { - Uses team-based care } \\
\text { to provide accountable } \\
\text { and coordinated care } \\
\text { to meet patient needs } \\
\text { Demonstrates } \\
\text { knowledge of billing } \\
\text { and the health } \\
\text { insurance system and } \\
\text { its effect on patients } \\
\text { Participates in a roots } \\
\text { cause analysis } \\
\text { Partners with } \\
\text { clinicians to decrease } \\
\text { medical costs by } \\
\text { adhering to imaging } \\
\text { appropriateness } \\
\text { criteria }\end{array}$ & $\begin{array}{l}\text { - Leads ambulatory } \\
\text { and inpatient teams } \\
\text { in using resources } \\
\text { efficiently and cost } \\
\text { conscientiously in } \\
\text { complex cases } \\
\text { - Serves on a hospital } \\
\text { committee } \\
\text { - Serves on an } \\
\text { academic committee } \\
\text { at own facility } \\
\text { - Leads a QI project } \\
\text { in your program } \\
\text { - Leads a roots cause } \\
\text { analysis } \\
\text { - Teaches seamless } \\
\text { transitions of care }\end{array}$ & $\begin{array}{l}\text { - Serves as a } \\
\text { director of a } \\
\text { division (PreDoc, } \\
\text { Residency, } \\
\text { Research, } \\
\text { Clinical) within } \\
\text { department } \\
\text { - Serves as officer } \\
\text { or delegate to } \\
\text { local or state } \\
\text { professional } \\
\text { organization } \\
\text { - Serves as } \\
\text { chairman of } \\
\text { committee within } \\
\text { educational } \\
\text { system or medical } \\
\text { center }\end{array}$ & $\begin{array}{l}\text { - Serves as delegate, } \\
\text { officer, or chairman } \\
\text { of a national or } \\
\text { international } \\
\text { organization } \\
\text { - Serves as } \\
\text { consultant to } \\
\text { national or } \\
\text { international } \\
\text { committees } \\
\text { - Serves as chair } \\
\text { of an academic } \\
\text { department } \\
\text { - Serves as a } \\
\text { member of clinical/ } \\
\text { multidisciplinary } \\
\text { national } \\
\text { committees } \\
\text { academically or } \\
\text { clinically }\end{array}$ \\
\hline
\end{tabular}

(continued on next page) 
Figure 1: Continued

\begin{tabular}{|c|c|c|c|c|}
\hline & Level 1 & Level 2 & Level 3 & Level 4 \\
\hline $\begin{array}{l}\text { Practice-based } \\
\text { learning \& } \\
\text { improvement }\end{array}$ & $\begin{array}{l}\text { - Demonstrates critical } \\
\text { appraisal of research } \\
\text { using set criteria } \\
\text { - Analyzes personal } \\
\text { development as a } \\
\text { physician and uses } \\
\text { a learning plan to } \\
\text { advance skills } \\
\text { - Initiates quality } \\
\text { improvement } \\
\text { project in clinical or } \\
\text { radiological endeavor } \\
\text { - Principles of evidence- } \\
\text { based care and } \\
\text { information mastery } \\
\text { are foundation of } \\
\text { clinical practice }\end{array}$ & $\begin{array}{l}\text { - Designs, performs, } \\
\text { and analyzes a } \\
\text { case-control study } \\
\text { - Design/leads a } \\
\text { journal club on } \\
\text { critical appraisal of } \\
\text { medical literature } \\
\text { - Manages quality } \\
\text { improvement for a } \\
\text { clinical entity } \\
\text { - Supervises/ } \\
\text { directs quality } \\
\text { improvement } \\
\text { initiatives for } \\
\text { learners }\end{array}$ & $\begin{array}{l}\text { - Designs, performs, } \\
\text { and analyzes } \\
\text { prospective } \\
\text { studies (double- } \\
\text { blind, controlled) } \\
\text { - } \text { Creates protocols } \\
\text { for continuous } \\
\text { review of practice } \\
\text { procedures } \\
\text { and outcomes } \\
\text { in department } \\
\text { or medical } \\
\text { community } \\
\text { - Strives through } \\
\text { clinical systemic } \\
\text { activities to } \\
\text { improve the } \\
\text { patient experience } \\
\text { of care, improve } \\
\text { the health of } \\
\text { populations, and } \\
\text { reduce the cost of } \\
\text { health care } \\
\text { Submits and } \\
\text { receives funding } \\
\text { for a research } \\
\text { project } \\
\text { Constructs } \\
\text { a faculty } \\
\text { development } \\
\text { curriculum/ } \\
\text { seminar }\end{array}$ & 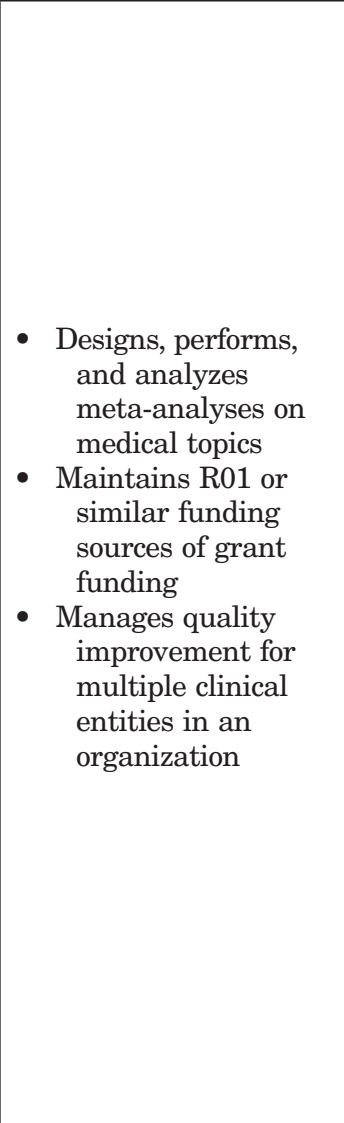 \\
\hline Professionalism & $\begin{array}{l}\text { - Fulfills the professional } \\
\text { obligations/ } \\
\text { responsibilities of your } \\
\text { medical specialty } \\
\text { - Models professional } \\
\text { personal behavior } \\
\text { exhibiting self- } \\
\text { awareness, self- } \\
\text { management, } \\
\text { social awareness } \\
\text { and relationship } \\
\text { management } \\
\text { Demonstrates value } \\
\text { for a patient's beliefs, } \\
\text { mores, and cultural } \\
\text { practices in shared } \\
\text { understanding of } \\
\text { patient care plans } \\
\text { Recognizes problems } \\
\text { and seek to find } \\
\text { solutions }\end{array}$ & $\begin{array}{l}\text { - Develops a shared } \\
\text { appreciation of } \\
\text { learner and work in } \\
\text { partnership to meet } \\
\text { their personal and } \\
\text { professional goals } \\
\text { - Demonstrates } \\
\text { ability to work } \\
\text { effectively with } \\
\text { faculty in meeting } \\
\text { department/ } \\
\text { residency/ } \\
\text { institutional goals } \\
\text { - Serves as a mentor } \\
\text { for learners }\end{array}$ & $\begin{array}{l}\text { Demonstrates } \\
\text { a high-level of } \\
\text { ethics in working } \\
\text { with the media, } \\
\text { representatives } \\
\text { of regulatory } \\
\text { bodies, and the } \\
\text { government } \\
\text { - Demonstrates } \\
\text { a high-level } \\
\text { of ethics and } \\
\text { understanding } \\
\text { in professional/ } \\
\text { personal } \\
\text { relationships with } \\
\text { colleagues } \\
\text { Serves as mentor } \\
\text { for faculty }\end{array}$ & $\begin{array}{l}\text { Exemplifies and role } \\
\text { models leadership, } \\
\text { scholarship, and } \\
\text { professionalism } \\
\text { in all aspects of } \\
\text { interaction } \\
\text { - Receives recognition } \\
\text { for outstanding } \\
\text { service and } \\
\text { dedication in } \\
\text { field of practice } \\
\text { in national or } \\
\text { international arena }\end{array}$ \\
\hline
\end{tabular}


Figure 1: Continued

\begin{tabular}{|c|c|c|c|c|}
\hline & Level 1 & Level 2 & Level 3 & Level 4 \\
\hline Communication & $\begin{array}{l}\text { - Demonstrates respect } \\
\text { for a patient's } \\
\text { autonomy in their } \\
\text { health decisions } \\
\text { - Delivers difficult } \\
\text { information regarding } \\
\text { personal health issues } \\
\text { empathetically and } \\
\text { effectively } \\
\text { - Uses electronic } \\
\text { health Record in } \\
\text { communicating with } \\
\text { health care team } \\
\text { - Demonstrates effective } \\
\text { and ethical use of } \\
\text { communication } \\
\text { systems } \\
\text { Delivers information to } \\
\text { fellow members of the } \\
\text { academic community } \\
\text { empathetically and } \\
\text { effectively using } \\
\text { multiple forms of } \\
\text { communication }\end{array}$ & $\begin{array}{l}\text { - Builds effective } \\
\text { rapport with } \\
\text { learners in a clinical } \\
\text { environment } \\
\text { - Presents didactic } \\
\text { information in } \\
\text { small group and } \\
\text { lecture formats } \\
\text { demonstrating } \\
\text { recognition of } \\
\text { learning style of } \\
\text { students/residents/ } \\
\text { clinicians } \\
\text { - Demonstrates } \\
\text { ability in leading } \\
\text { an ambulatory, } \\
\text { inpatient, or } \\
\text { imaging team/ } \\
\text { service that fosters } \\
\text { trust, respect, and } \\
\text { understanding }\end{array}$ & $\begin{array}{l}\text { - Works well with } \\
\text { difficult learners } \\
\text { and develop } \\
\text { remediation } \\
\text { plans which } \\
\text { may accomplish } \\
\text { learner and } \\
\text { institutional goals } \\
\text { - Recognizes } \\
\text { and utilize } \\
\text { the principles } \\
\text { of conflict } \\
\text { management in } \\
\text { difficult situations } \\
\text { Demonstrates } \\
\text { success in } \\
\text { managing } \\
\text { change at the } \\
\text { department/ } \\
\text { institutional level }\end{array}$ & $\begin{array}{l}\text { - Demonstrates } \\
\text { leadership in } \\
\text { cultural proficiency, } \\
\text { understanding of } \\
\text { health disparities, } \\
\text { and social } \\
\text { determinants of } \\
\text { health in national/ } \\
\text { international } \\
\text { situations } \\
\text { - Excels in conflict } \\
\text { management and } \\
\text { in deescalating } \\
\text { difficult situations }\end{array}$ \\
\hline
\end{tabular}

Table 1: Demographic Characteristics

\begin{tabular}{|l|c|c|}
\hline \multicolumn{1}{|c|}{ Variable } & Level & Statistic \\
\hline Years in academia & - & $15.8(12.2)$ \\
\hline Academic department & & \\
\hline & Ob-Gyn & $21(39.6 \%)$ \\
\hline & OMFS/ENT & $6(11.3 \%)$ \\
\hline & Pathology & $5(9.4 \%)$ \\
\hline & Radiology & $8(15.1 \%)$ \\
\hline Academic appointment & Surgery & $13(24.5 \%)$ \\
\hline & & \\
\hline & Instructor & $2(3.8 \%)$ \\
\hline & Assistant professor & $23(43.4 \%)$ \\
\hline & Associate professor & $9(17.0 \%)$ \\
\hline & Professor & $18(34.0 \%)$ \\
\hline
\end{tabular}

Abbreviations: Ob-Gyn, obstetrics-gynecology; OMFS, oral and maxillofacial surgery; ENT, ear, nose and throat.

\section{Discussion}

The milestones (Figure 1) identify four levels of progression in a career in academic medicine. The initial level defines those skills based on the six core competency categories for physicians who recently graduated from their residency program. Each core competency establishes activities universal in academics, helping to additionally recognize the
The competency of communication did not appear to correlate well with years of teaching and academic rank. This may be for a variety of reasons including the need for physician educators to have established skill sets in communication, or it may be related to self-perceived competency and difficulty on self-evaluation of competency. This may be an area that is more challenging to assess and quantify without external grading and mentorship.

While it is difficult to score accomplishments across a diverse set of faculty respondents, overall higher academic rank resulted in meeting a higher level of competency. Success in an academic career does not necessarily correlate with a level of competency achievement. The development of doctor/patient relationships, clinical skills, and the internal satisfaction gained from helping develop medical learners and heal patients are fulfilling regardless of academic promotion or career progression. Physicians will gravitate to the levels of their interest and expertise based on their personal characteristics and skills. It is for this reason that these guidelines should 
Table 2: Descriptive Statistics for Between-Subjects Analyses

\begin{tabular}{|l|c|c|c|c|}
\hline \multicolumn{1}{|c|}{ Area } & $\begin{array}{c}\text { Assistant } \\
\text { Professor }\end{array}$ & $\begin{array}{c}\text { Associate } \\
\text { Professor }\end{array}$ & Professor & $\boldsymbol{P}$ Value \\
\hline Patient care & $3.0(1.5)$ & $3.0(0.0)$ & $4.0(1.0)$ & .037 \\
\hline Medical knowledge & $2.7(0.8)$ & $2.9(0.7)$ & $3.4(0.5)$ & .008 \\
\hline System-based practice & $2.0(2.0)$ & $2.5(1.3)$ & $4.0(1.0)$ & .001 \\
\hline $\begin{array}{l}\text { Practice-based learning and } \\
\text { improvement }\end{array}$ & $2.5(1.0)$ & $2.5(0.5)$ & $3.0(0.9)$ & .001 \\
\hline Professionalism & $3.1(0.9)$ & $2.8(0.6)$ & $3.5(0.6)$ & .055 \\
\hline Communication & $3.0(2.0)$ & $3.0(0.3)$ & $4.0(1.0)$ & .620 \\
\hline
\end{tabular}

not function as a ruler or plumb line to evaluate an individual's success or serve as an essential process in defining a productive academic career, but rather should function only as a tool for faculty development.

\section{Limitations}

We scored this rubric as a self-assessment only, possibly limiting the reliability of the data, since physicians can have difficulty with self-assessment. ${ }^{7}$ It is difficult to ascertain the utility of this tool based on the current methods of administration. The methods could be strengthened if each faculty surveyed also submits a curriculum vitae (CV) for review by the investigators using a rubric to match achievements on the $\mathrm{CV}$ to the milestone model. One-on-one interviews with the faculty could allow examiners to explain the criteria to more accurately complete the milestone rubric. Further customization of the rubric may be necessary to reflect alternative tracks for career advancement, such as a primarily clinical track.

\section{Conclusions}

This rubric has been helpful in our institution, providing feedback for directing faculty development and establishing career scholarly activity goals and faculty mentorship. We have recently recruited from within our residency program,${ }^{8}$ and it has helped our new faculty to quickly become knowledgeable about the expectations of an academician. These milestones are general enough that other physician specialties may be able to adopt them for their needs. The next goals are to externally validate the milestones, first among departments of family medicine, and then among similar academic medical centers, and ultimately establish uniform guidance for the professional development of career physician educators. Further studies could also focus on the usefulness of this rubric to help retain faculty within academic medicine.

CORRESPONDING AUTHOR: Address correspondence to Dr Rebecca K. Kemmet, Department of Family Medicine, University of Tennessee Graduate School of Medicine, 1924 Alcoa Highway, Knoxville, TN 37920. 865-3055056.rkemmet@utmck.edu.

\section{References}

1. Edgar L, Roberts S, Holmboe E. Milestones 2.0: A Step Forward. J Grad Med Educ. 2018;10(3):367-369. https://doi.org/10.4300/ JGME-D-18-00372.1

2. Srinivasan M, Li ST, Meyers FJ, et al. "Teaching as a competency": competencies for medical educators. Acad Med. 2011;86(10):1211-1220. doi:10.1097/ACM.0b013e31822c5b9a

3. Görlitz A, Ebert T, Baver D, Grast M, Hofer M, Lammerding-Köppel M, Fabry G. Core Competencies for Medical Teachers (KLM). A position paper of the GMA Committee on Personal and Organizational Development in Teaching. GMS Zeitschrift für Medizinische Austiktung. 2015; Vol. 32(2); 1/14-7/14

4. Bing-You R, Holmboe E, Varaklis K, Linder J. Is it time for entrustable professional activities for residency program directors? Acad Med. 2017;92:739-742. doi:10.1097/ ACM.0000000000001503

5. Heath JK, Dine CJ, Burke AE, Andolsek KM. Teaching the teachers with milestones: using the ACGME milestones model for professional development. J Grad Med Educ. 2021;13(2)(suppl):124-126. doi:10.4300/JGMED-20-00891.1

6. Blake GH, Kemmet RK, Jenkins J, Heidel RE, Wilson GA. Milestones as a guide for academic career development. Fam Med. 2019;51(9):760 765. doi:10.22454/FamMed.2019.109290

7. Davis DA, Mazmanian PE, Fordis M, Van Harrison $\mathrm{R}$, Thorpe KE, Perrier L. Accuracy of physician self-assessment compared with observed measures of competence: a systematic review. JAMA. 2006;296(9):1094-1102. doi:10.1001/ jama.296.9.1094

8. Wilson GA, Jenkins J, Blake GH. Recruiting faculty from within: filling the growing need for family medicine faculty. J Reg Med Campuses. 2020;3(1):1. doi:10.24926/jrmc.v3i1.2149 